\title{
ЭВОЛЮЦИЯ МЕТОДОВ, ИСПОЛЬЗУЕМЫХ ОРГАНИЗОВАННОЙ ПРЕСТУПНОСТЬЮ КАК ФАКТОР, ПОВЫШАЮЩИЙ СТЕПЕНЬ ОБЩЕСТВЕННОЙ ОПАСНОСТИ
}

\section{Рязанова Екатерина Николаевна}

адъюнкт

Санкт-Петербургский университет МВД России

Аннотация: В статье рассмотрено влияние информационнокоммуникационных технологий на эволюцию способов совершения преступлений. Отмечено усиление негативного влияния преступных сообществ на экономическую сферу. Обозначены угрозы, которые могут возникнуть в будущем при росте вовлеченности преступных сообществ в сферу ИКТ.

Ключевые слова: информационно-коммуникационные технологии, преступные сообщества, сеть-Интернет.

\section{EVOLUTION OF METHODS USED BY ORGANIZED CRIME AS A FACTOR THAT INCREASES THE DEGREE OF PUBLIC DANGER}

\section{Ryazanova Ekaterina Nikolaevna}

Abstract: The article examines the influence of information and communication technologies on the evolution of ways of committing crimes. The strengthening of the negative influence of criminal communities on the economic sphere was noted. The threats that may arise in the future with the growing involvement of criminal communities in the field of ICT are outlined.

Key words: information and communication technologies, criminal communities, the Internet.

C помощью информационно-коммуникационных технологий люди получили возможность связываться друг с другом по всему миру. СетьИнтернет - это с одной стороны уникальная возможность для общения, обмена информацией, пользования услугами, с другой стороны, платформа для совершения преступлений.

Ученые-криминологи в качестве движущей силы преступности выделяют организованную профессиональную преступность [1, с. 34]. 
Представители организованной преступности также обратили внимание на сферу ИКТ, оценив преимущества использования современных технологий, прежде всего их доступность и анонимность. Основными преступными деяниями, совершаемыми при помощи сети-Интернет, являются мошенничество, организация и проведение он-лайн азартных игр, получение, разглашение сведений, составляющих коммерческую, налоговую и банковскую тайну, неправомерный доступ к компьютерной информации, оборот средств платежей, а также распространение вредоносного программного обеспечения.

Если мошенничество, азартные игры преимущественно ориентированы на завладение денежными средствами граждан, то другие из перечисленных деяний направлены в основном в отношении международных компаний.

Вредоносное программное обеспечение является преобладающим способом совершения преступлений и это несмотря на то, что в бюджет таких организаций закладываются существенные денежные средства для обеспечения информационной безопасности. Поэтому для создания вредоносного программного обеспечения преступными сообществами привлекаются высококвалифицированные специалисты (студенты, выпускники по направлению обучения IT-технологии), способные разрабатывать «вирусы», «черви» и «трояны» для обхода имеющейся защиты.

Так, в январе 2022 года в Российской Федерации была пресечена деятельность одной из крупнейших хакерских международных мошеннических преступных сообществ - The Infraud Organization. Ущерб от действий которой только в США по предварительным оценкам составил более 560 млн американских долларов. Члены данной группировки создали платформу Infraud, которая предоставляла сервисы для совершения мошенничеств в сетиИнтернет. Они также взломали и реализовали информацию третьим лицам о более, чем 4 млн дебетовых и кредитных картах. Насмехаясь над установленными в обществе порядками и понимая, что доказать их причастность к преступным деяниям довольно затруднительно, они стали именовать себя как «Министерство мошеннических дел», а в качестве своего девиза избрали слоган «Мы верим в обман». Что говорит об уверенности в своей неуязвимости.

Немного ранее было ликвидировано хакерское преступное сообщество REvil [2], специализирующееся на похищении, с использованием вредоносного программного обеспечения, денежных средств со счетов иностранных граждан и компаний. Одним из способов, которым они пользовались, являлось 
шифрование похищенной информации и последующее вымогательство денежных средств за ее раскодирование. Только за 2020 год прибыль данного преступного сообщества составила более 100 млн американских долларов. Жертвами преступной деятельности становились крупные международные компании, как, например, Apple, JBS, Kaseya, Aser. Выбор таких компаний обусловлен их платежеспособностью, возможностью внести выкуп в сумме более миллиона долларов.

По оценкам экспертов компьютерные атаки обходятся американским компаниям приблизительно в полмиллиарда долларов в год. Глобальный ущерб от такого рода притуплений в 2020 году превысил 2 триллиона долларов [3].

Для совершения преступлений членами данных преступных сообществ в сети-Интернет создавалась своя инфраструктура: сервера, сайты, в том числе в Даркнете, аккаунты, блоги, техническая поддержка и самое важное программное обеспечение (софт). Даркнет или темный Интернет активно используются преступниками для сокрытия своих данных и используемых для этих целей информационных технологий. Здесь хранят, продают и покупают вредоносное программное обеспечение, обмениваются эксплойтами (фрагмент программного обеспечения, находящая и использующая ошибку или уязвимость, для непреднамеренного поведения устройства, на котором оно установлено).

По мнению экспертов, размер темного Интернета не индексируемого и недоступного для поисковых систем в 5 тысяч раз превышает размер доступной сети-Интернет и продолжает расти со скоростью, не поддающейся качественной и количественной оценке.

Согласно отчету Всемирного экономического форума, посвященного глобальным проблемам, организованная преступность объединяет свои усилия в сети-Интернет, делая возможность обнаружения их преступной деятельности и дальнейшего судебного преследования равной примерно пяти сотой процента [4].

Однако, появляющиеся в средствах массовой информации данные о пресечении деятельности отдельных организованных преступных групп в киберпространстве не могут давать оснований для оптимизма относительно снижения общего уровня киберпреступности, которая в реальности находится «на подъеме» [5].

При этом, деятельность организованных преступных групп наносит не только экономический ущерб, но и потерю производительности, кражу 
интеллектуальной собственности, персональных данных, репутационные потери. Целью преступников могут становиться и другие сферы деятельности, например политическая, связанная со стабильностью и межгосударственными отношениями.

Так, в конце января 2022 года преступная группа, именующая себя как «Киберпартизаны» заразили сеть государственной железнодорожной системы республики Беларусь с требованием прекратить оказывать помощь российским войскам в преддверии возможного вторжения в Украину [6].

Мы считаем, что в будущем количество таких случаев инцидентов возрастет. Преступные сообщества, заполучив значительные капиталы в свое распоряжение, сосредоточатся на создании напряженности в отдельных государствах. Так, атакам может подвергнуться социальная сфера, отдельные предприятия, организации, учреждения здравоохранения, (больницы, поликлиники), правоохранительные органы, отдельные объекты, такие как автомобили, самолеты, железные дороги, электросети и т.п.

Российская Федерация, осознавая масштабность таких угроз, в июле 2021 года внесла в Спецкомитет ООН проект универсальной международной конвенции по противодействию использования информационнокоммуникационных технологий в преступных целях [7].

Таким образом, ценность информационно-коммуникационных технологий заключается не только в доступности предоставляемых с их помощью услуг и возможностей, но и защищенностью от потенциальных угроз.

\section{Список литературы}

1. Долгова, А.И. Криминологические оценки организованной преступности и коррупции, правовые баталии и национальная безопасность. М., Российская криминологическая ассоциация, 2011. - 665 с.

2. РосБизнеКонсалтинг. Разгром хакерской группировки REvil. Что важно знать. [Электронный ресурс] - URL //nhttps://www.rbc.ru/society/16/01/ 2022/61e1969c9a7947af9169663b (дата обращения: 20.01.2022).

3. Важная статистика киберпреступности. [Электронный ресурс] URL // https://financesonline.com/cybercrime-statistics/ (дата обращения: 25.01.2022).

4. Отчет Всемирного экономического форума «Глобальные проблемы в 2020 году». [Электронный ресурс]. - URL // https://www3.weforum.org/docs/ WEF_Global_Risk_Report_2020.pdf (дата обращения: 26.02.2022). 
5. Осипенко, А.Л. Организованная преступная деятельность в киберпространстве: тенденции и противодействие // Юридическая наука и практика: Вестник Нижегородской академии МВД России. 2017. №4 (40). URL: https://cyberleninka.ru/article/n/organizovannaya-prestupnaya-deyatelnost-vkiberprostranstve-tendentsii-i-protivodeystvie (дата обращения: 27.01.2022).

6. Гудин Дэн. Активисты заявляют, что взломали железнодорожную систему Беларуси, чтобы остановить наращивание российской военной мощи. [Электронный ресурc] - URL // https://arstechnica.com/information-technology/ 2022/01/hactivists-say-they-hacked-belarus-rail-system-to-stop-russian-militarybuildup/ (дата обращения: 25.02.2022).

7. Проект Конвенции Организации Объединенных наций о противодействии использованию информационно-коммуникационных технологий в преступных целях. [Электронный ресурс] - URL // https:// www.kommersant.ru/docs/2021/RF_28_July_2021_-_R.pdf (дата обращения: 27.01.2022).

(C) Е.Н. Рязанова, 2022 